\title{
Pericardial Tube
}

National Cancer Institute

\section{Source}

National Cancer Institute. Pericardial Tube. NCI Thesaurus. Code C122598.

A hollow tube that is inserted into the pericardium through a surgical incision in the chest wall. 